CASE REPORT

\title{
Testicular seminoma in a patient with a constitutively activating mutation of the luteinizing hormone/chorionic gonadotropin receptor
}

\author{
Malcolm M Martin ${ }^{1}$, Shao-Ming Wu ${ }^{1}$, Arline L A Martin ${ }^{1}$, Owen M Rennert ${ }^{1}$ and Wai-Yee Chan ${ }^{1,2}$ \\ ${ }^{1}$ Department of Pediatrics and ${ }^{2}$ Departments of Cell Biology, Biochemistry and Molecular Biology, Georgetown University Medical Center, \\ Washington DC 20007, USA \\ (Correspondence should be addressed to W-Y Chan, Department of Pediatrics, Georgetown University Children's Medical Center, 3800 Reservoir Road, \\ NW, Washington DC 20007, USA)
}

\begin{abstract}
A white man who had been diagnosed, 35 years previously at the age of 27 months, to have precocious puberty, was later determined to have familial male-limited precocious puberty (FMPP), on the basis of his family history, increased serum testosterone, prepubertal concentrations of follicle stimulating hormone and luteinizing hormone, and Leydig cell hyperplasia. Recently, this diagnosis was confirmed by molecular genetic analysis that demonstrated the presence of a heterozygous constitutive activating mutation of the luteinizing hormone/chorionic gonadotropin receptor. This dominant gain-of-function Asp578Gly mutation has been shown constitutively to activate the receptor in the absence of the agonist, leading to enhanced synthesis of cAMP and, in turn, to increased, sustained production of testosterone. In 1994, this patient was found to have a testicular seminoma. He represents the first case of a testicular germ cell tumor described in an FMPP patient, raising the possibility of a potentially harmful effect of prolonged increased concentrations of sex hormones, with onset early in life, upon the cellular components of the testes.
\end{abstract}

European Journal of Endocrinology 139 101-106

\section{Introduction}

Familial male-limited precocious puberty (FMPP) is a form of isosexual precocious true puberty in boys, and is independent of gonadotropin releasing hormone (GnRH) (1, 2). An autosomal dominant mutation leads to progressive Leydig cell activation with signs of puberty generally appearing by $3-4$ years of age $(3,4)$.

Recently, a number of missense mutations of the human luteinizing hormone/chorionic gonadotropin receptor (hLHR), a G-protein-coupled receptor, have been identified in FMPP kindreds (5). These mutations give rise to constitutive activation of the hLHR, leading to ligand-independent production of intracellular cAMP and, in turn, testosterone. Constitutively activated mutant forms of G-protein-coupled receptors and of various $\mathrm{G}$ proteins may lead to cellular transformation and the development of neoplasms $(6,7)$.

In this report, we describe a patient who was diagnosed clinically 35 years ago with precocious puberty, documented later as GnRH-independent, who developed a testicular seminoma. Testicular seminoma is a relatively rare tumor that is known to occur more frequently in cryptorchid testes, gonadal dysgenesis, and in patients with androgen insensitivity syndrome, but has not previously been described in a patient with FMPP. The occurrence of two rare disorders in this patient could be attributable to chance; however, the possibility that the two are related should not be ignored.

\section{Case report}

The patient, a white male, was first seen at Georgetown University Medical Center in 1961 at age 27 months, for evaluation of precocious sexual development. He was the offspring of a normal second pregnancy, but was born 4 weeks prematurely, weighing $2.03 \mathrm{~kg}$. Early growth and development seemed normal. However, by the time he was 2 years of age, his mother became aware of enlargement of the genitals, and the appearance of pubic hair. The family history was remarkable in that the father had an early onset of puberty, with an adult height of $1.68 \mathrm{~m}$.

At age 27 months, the patient's height and weight were 90th percentile for age. His head circumference was $53.3 \mathrm{~cm}$ (above the 97th percentile for age). 
Significant findings were an enlarged phallus $(9.0 \times 2.5$ $\mathrm{cm})$ with a corrugated scrotum containing testes measuring $2.4 \times 1.4 \mathrm{~cm}$ on the left and $2.3 \times 1.2 \mathrm{~cm}$ on the right. There were approximately 20 pigmented, coarse hairs on the pubis and the prostate was palpable on rectal examination. The remainder of the physical examination was normal. Urine analysis, blood chemical and hematological values and urinary steroid excretion were normal for age, as were an i.v. pyelogram and electroencephalogram. The bone age was 3 years. A pneumoencephalogram demonstrated an enlarged ventricular system, but no other abnormality. Testicular biopsy showed interstitial cell hyperplasia and evidence of early spermatogenesis. A test for urinary follicle stimulating hormone (FSH) was negative at that time, but positive 18 months later. A second testicular biopsy documented considerable progression reflecting early puberty. Idiopathic precocious puberty, secondary to hydrocephalus, was believed to be the most likely diagnosis.

Over the next several years, the patient continued his rapid growth and maturation. He was given a trial of medroxyprogesterone acetate; because of an allergic reaction, his mother discontinued the medication. At age 4 years and 2 months, the patient had a height age of 7.5 years, presented as a virilized boy with a deep voice, had abundant black pubic hair and was Tanner stage $\mathrm{P} 3 / 4$. The bone age was 11 years. A repeat of the ventriculogram was unchanged. A nuclear brain scan demonstrated no central nervous system lesion. Steroid studies excluded adrenogenital syndrome. The testosterone secretion rate was $1.5 \mathrm{mg} / 24 \mathrm{~h}$ (normal prepubertal secretion rate $0.4-0.7 \mathrm{mg} / 24 \mathrm{~h}(8))$. By age 6.5 years, the patient was pubertal stage $4 / 5$ and had a bone age of 13 years. At age 10 years he had fused his epiphyses, and presented as a mature, short, muscular male, with a height of $1.54 \mathrm{~m}$.

In 1988 at the age of 28 years (Fig. 1), the patient returned to Georgetown University Medical Center for evaluation of infertility having been found to have oligospermia, sperm with poor motility, low serum concentrations of FSH and luteinizing hormone (LH), increased serum prolactin and an adult concentration of serum testosterone. He claimed to be in good health and experienced normal libido and ejaculations. System review was unremarkable. He was employed as a sports teacher. He was short $(1.56 \mathrm{~m})$, stocky $(68.04 \mathrm{~kg})$, muscular, hirsute, and moderately obese. His arms and legs were short in relation to his trunk. The head appeared large, as before. The phallus measured $11.5 \mathrm{~cm}$ in the flaccid state and was thick. The testes were soft and small $(3.6 \times 1.4 \mathrm{~cm}$ bilaterally); the left testis was tender to the touch. The remainder of the physical examination was normal. Urine analysis, hematocrit, sedimentation rate, serum chemical determinations, thyroid function tests, and adrenal steroid concentrations were normal. Computerized tomography (CT) of the brain showed a somewhat enlarged

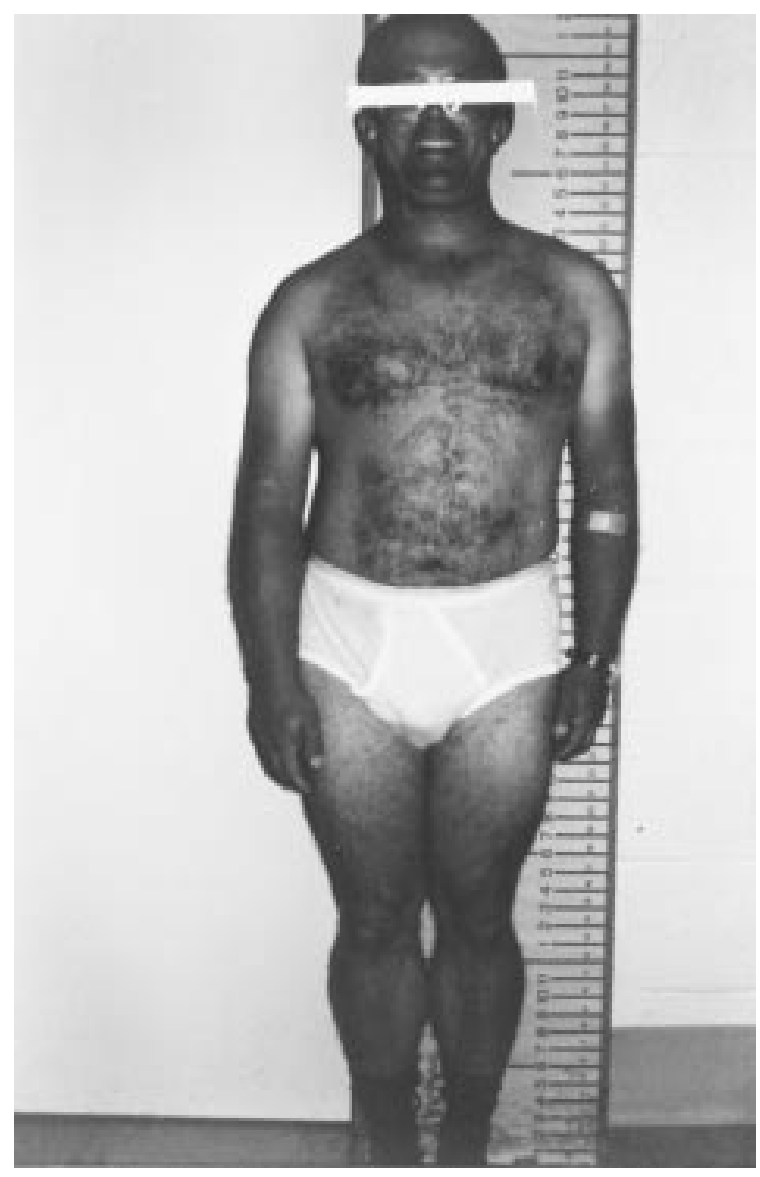

Figure 1 The patient at 28 years of age.

ventricular system as before, but was otherwise unrevealing.

In the autumn of 1994 , the patient complained of pain in the left testicle. Initially he was treated for epididymitis. In December of 1994, an ultrasound examination of the left testicle showed extensive nonhomogeneous echopenic areas, which could represent resolving orchitis, but the possibility of malignancy could not be ruled out. Ultrasound of the right testis was normal. In January 1995, the left testis was surgically removed and reported as a seminoma without invasion or penetration of the tunica albuginea. An abdominal CT scan revealed abdominal lymph node enlargement. The patient received three cycles of chemotherapy with cis-platin, etoposide and bleomycin sulfate. He responded well to this management and is asymptomatic at the time of this writing.

\section{Laboratory studies}

\section{Endocrine studies}

Hormone studies in 1988 when the patient was 28 years of age showed serum testosterone $(17.6 \mathrm{nmol} / \mathrm{l})$ and 
dehydroepiandrosterone sulfate (DHEAS) $(8.89 \mu \mathrm{mol} / \mathrm{l})$ to be normal. Serum FSH and LH concentrations were below the detection sensitivity of the RIA method. Prolactin was increased, at $36.7 \mu \mathrm{g} / \mathrm{l}$. A cortrosyn stimulation test $(0.25 \mathrm{mg}$ i.v. over $5 \mathrm{~min})$ showed a normal response of cortisol, $17 \alpha$-hydroxyprogesterone and 11-desoxycortisol. Repeat measurement of FSH and LH concentrations revealed them to be low $(<1.4$ and $<2.5 \mathrm{IU} / \mathrm{l}$ respectively) and there was no response to $100 \mu \mathrm{g}$ i.v. administered GnRH given over $2 \mathrm{~min}$ (maximum responses: FSH $1.4 \mathrm{IU} / \mathrm{ml}$, LH $6.0 \mathrm{IU} / \mathrm{l}$ (9)).

\section{Histopathological studies}

In our institution, most fixed tissue, paraffin blocks and microscopic preparations that are 30 years old may be expected to have been discarded by the Department of Pathology. Of the two testicular biopsies performed on this patient, only a slide preparation from 1961 was available. At that time he was 27 months old. Because of fading, it was necessary to re-stain the tissue. The gross narrative described the biopsy as an irregularly shaped fragment $0.7 \times 0.6 \times 0.3 \mathrm{~cm}$. The entire specimen was fixed in Bouin's solution. Sections were stained with hematoxylin and eosin (H\&E). They showed testicular tissue with tightly packed seminiferous tubules. An occasional tubule showed a few spermatogonia and primary spermatocytes. No spermatogenesis was noticed. The interstitium contained many interstitial cells (Fig. 2). This slide was reviewed at the Armed Forces Institute of Pathology. The reviewer concurred with the above description of the biopsy. No mention was made of abnormal cells. The control section was from autopsy material of an age-matched subject who died of causes unrelated to testicular pathology.

A second testicular biopsy in 1963, when the patient was aged 3 years and 10 months, was described grossly as measuring $1.2 \times 0.5 \times 0.5 \mathrm{~cm}$. A small portion of capsule was noted. The tissue was fixed in Bouin's solution. H\&E sections revealed seminiferous tubules composed both of Sertoli cells and of germ cells in various stages of maturation. Occasional tubules exhibited spermatocytes. Aggregates of interstitial cells were noted. Compared with the previous biopsy this section of the testis revealed considerable maturation and corresponded to an early pubertal change.

In 1995 the patient had a left orchiectomy. The tissue measured $5.0 \times 3.5 \times 2.5 \mathrm{~cm}$. On cut section, the normal gross pattern was absent and replaced by tumor with areas of necrosis and hemorrhage. Examination of a formalin-fixed H\&E section (Fig. 3) revealed a pattern compatible with a seminoma - namely, large cells with somewhat indistinct borders, vacuolated cytoplasm, and nuclei of variable size with prominent nucleoli. Aggregates of lymphocytes were present within the tumor. There was no evidence of tumor extension into the tunica albuginea. A single field showed degenerated seminiferous tubules with fragmented, hyalinized basement

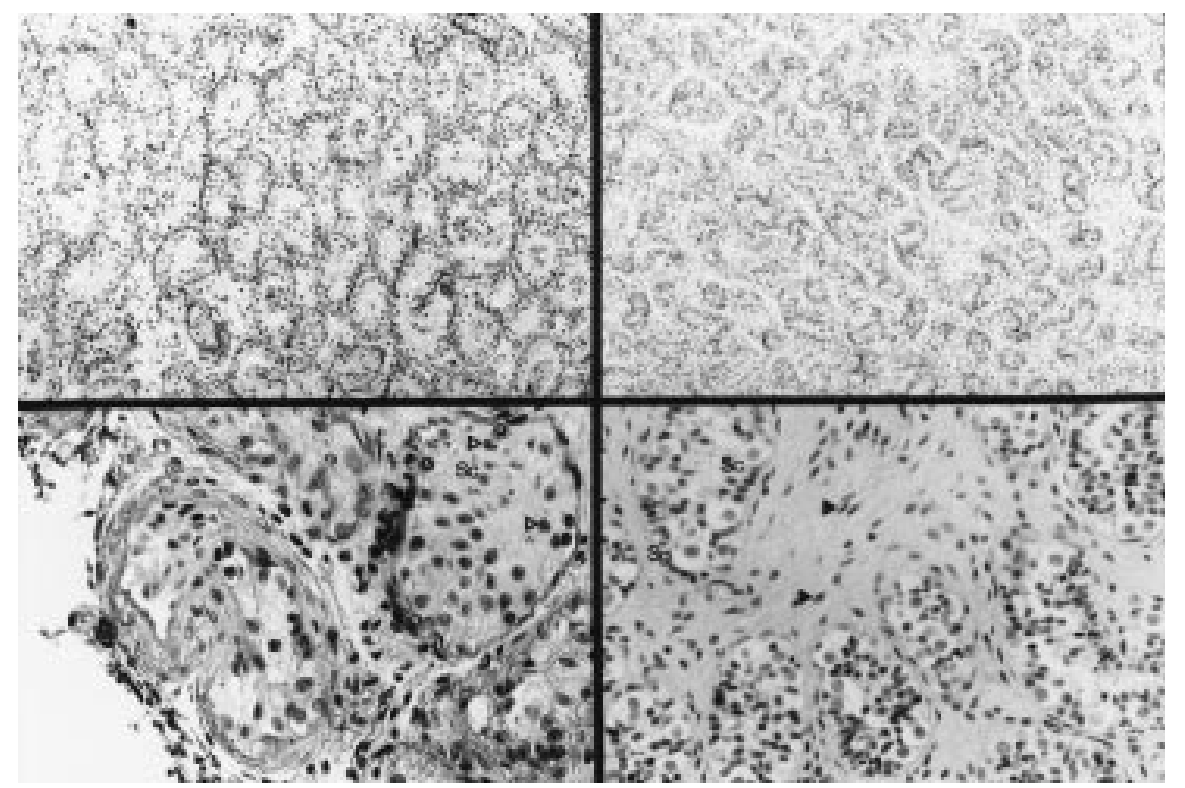

Figure 2 Top: H\&E section (original magnification, $\times 10$ ). Left: Testicular biopsy of the patient at age 27 months. The seminiferous tubules are aligned back to back, with open lumina. Right: Age-matched control. The seminiferous tubules are widely spaced, with narrow lumina, and are separated by broad bands of interstitium. Bottom: H\&E section (original magnification, $\times 40$ ). Left: The patient has seminiferous tubules lined by Sertoli cells (Sc) and spermatogonia (Sg). Spermatocytes in meiosis are present (open arrows). Aggregated Leydig cells are present between the contiguous seminiferous tubules. Right: The control has seminiferous tubules lined mostly by Sertoli cells (Sc) with fewer spermatogonia (Sg). There is no evidence of maturation. Leydig cells (solid arrows) are dispersed in the interstitium. 


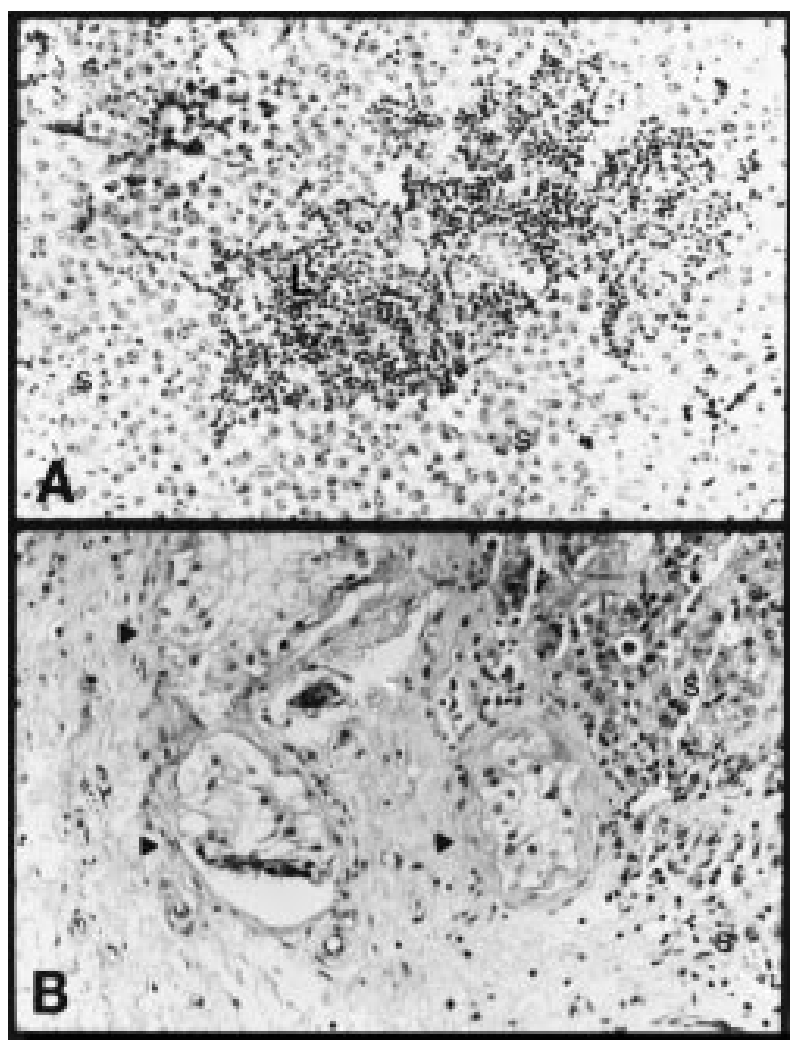

Figure 3 Testicular seminoma in the patient at age 35 years. H\&E section (original magnification, $\times 40$ ). A: Tumor $(\mathrm{S})$ infiltrated by lymphocytes (L). B: Seminoma cells $(S)$ encroaching on degenerated seminiferous tubules (solid arrows). The basement membranes are fragmented and hyalinized, and the tubules are lined by ballooned cells with pycnotic nuclei.

membranes; the lining cells were ballooned and had pycnotic nuclei.

\section{DNA studies}

Genomic DNA was isolated from peripheral blood. Exon 11 of the hLHR gene was amplified by polymerase chain reactions (PCR) and the nucleotide sequence determined directly from the PCR product (10). Mutations were determined by sequencing both strands generated by asymmetric PCR. Templates for asymmetric PCR were derived from two or more independent PCR reactions. PCR amplification of exon 11 of the hLHR gene gave one single DNA band (result not shown). Asymmetric PCR and direct sequencing of the product from this patient revealed an A to $G$ transition at nucleotide 1733 in one allele (Fig. 4). This heterozygous mutation resulted in the substitution of Gly for Asp578 in the transmembrane helix 6 of one allele of the hLHR (10). This study was approved by the Institutional Review Board of Georgetown University Medical Center with consent from the patient.
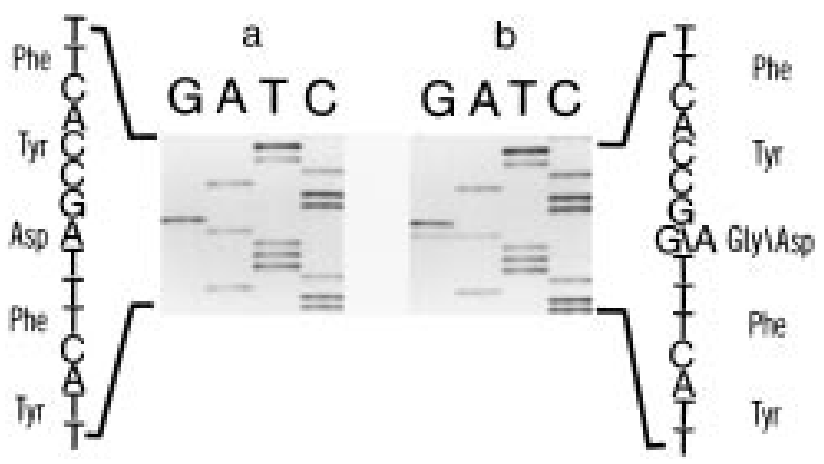

Figure 4 Missense mutation of the hLHR in the patient. (a) Normal sequence. (b) Heterozygous A1733G mutation of the human luteinizing hormone receptor in the patient.

\section{Discussion}

Puberty is unequivocally precocious when signs of sexual maturation appear before the age of 8 years in a girl or 9 years in a boy $(2,3)$. Increased circulating sex steroids lead to accelerated growth, somatic development, skeletal maturation, and early fusion of the epiphyses. These result in tall stature in childhood, but short adult height, though patients with idiopathic central precocious puberty may realize their full height potential (11). Before the availability of molecular diagnostics, the diagnosis of FMPP was based upon documentation of prepubertal concentrations of serum gonadotropins in the basal state and in response to GnRH stimulation, pubertal concentrations of serum testosterone secreted by the testes, and bilateral testicular enlargement with maturation of Leydig cells and germinal epithelium $(1,4)$. Recent identification of a molecular defect leading to constitutive activation of the hLHR pathway has provided the explanation for the pathophysiology of male-limited GnRH-independent precocious puberty (5).

The hLHR is a member of the family of G-proteincoupled receptors that, in the testes, mediates the effects of $\mathrm{LH}$ on testosterone biosynthesis. Of a total of 11 single-base mutations within exon 11 of the hLHR gene that have been identified among 68 kindreds of FMPP (5, and SM Wu, E Leschek \& WY Chan, unpublished observations), the most frequently observed is the A $1733 \mathrm{G}$ missense mutation that results in substitution of Gly for Asp578 in the transmembrane helix 6 of the hLHR (10). Expression studies of the mutated recombinant hLHR in cultured HEK 293 cells or COS-7 cells showed that these mutations cause constitutive activation of the hLHR in the absence of the agonist, resulting in increased basal production of cAMP (5) and, in turn, of testosterone (12).

A number of studies have shown that constitutive activation of the signal transduction pathway of $G$ protein-coupled receptors as a result of mutations of either the receptor or the $G$ protein may lead to neoplasia. Activation of $\mathrm{G}$ proteins, such as $\mathrm{G}_{\mathrm{i} 2} \alpha$ and 
$\mathrm{G}_{\mathrm{q}} \alpha$, cause cellular transformation in vitro $(6,7)$. In vivo mutations of $\mathrm{G}_{\mathrm{s}} \alpha$, which inhibit intrinsic GTPase activity, activate adenylyl cyclase in a receptorindependent way, giving rise to autonomous hormoneproducing tumors of pituitary somatotropes (13). Mutations of $\mathrm{G}_{\mathrm{i}} \alpha 1$ and $\mathrm{G}_{\mathrm{i}} \alpha 2$ have been described in functional sporadic thyroid adenomas and adrenal cortical tumors $(6,7)$. Constitutively activated mutations of some $\mathrm{G}$ protein-coupled receptors have also been shown to result in neoplasia. Mutant forms of the $\alpha 1 \mathrm{~B}$-adrenergic receptor have been shown to enhance mitogenesis and tumorigenicity (14). Somatic mutations activating the thyroid-stimulating hormone receptor have been shown to be a cause of toxic thyroid adenoma (15).

There is no clear evidence for a causative role of a mutated hLHR in the development of the testicular seminoma in the patient described, yet its potential cannot be dismissed. Few risk factors have been established for testicular germ-cell cancer. Perinatal exposure to sex hormones or 'hormonal disruption' is proposed as one factor influencing the risk of malignant changes (16-18). Early abnormal exposure to increased concentrations of sex hormones certainly occurs in FMPP, and sex hormones are known to stimulate the growth of cancer cells (19).

The patient presented here differs from most patients with FMPP in that he not only presented earlier than usual with evidence of abnormal androgen secretion, but he also continued to show lack of gonadotropin secretion when he was seen as an adult for infertility with oligospermia and poor sperm motility. It seems reasonable to suggest that the rapid bone maturation and early epiphyseal fusion in childhood were due, not to excessive testosterone secretion, but to estrogen, as a result of increased aromatase activity (20). Involvement of estrogen could also explain the low FSH and LH concentrations and the unresponsiveness to GnRH stimulation when he was seen for infertility, as estrogen, and not androgen, is now believed to regulate gonadotropin secretion (21). Serum estradiol, when measured after removal of the tumor in 1995, was not increased, nor did the patient clinically demonstrate gynecomastia. Nevertheless, it is not unreasonable to speculate that, early in life, exposure of the cellular elements within the immature testis to increased concentrations of estrogen or to an imbalance of estrogen/androgen modulation could lead directly or indirectly to malignant transformation.

When the patient was seen for evaluation of infertility in 1988, his left testis was tender to the touch. It is very likely that a biopsy at that time might have shown carcinoma in situ, or even a seminoma. The seminoma in this patient may have occurred by chance; however, a connection between FMPP and germ cell neoplasia, though speculative, is equally possible and should not be dismissed. Had such an association been proposed in 1988, the diagnosis might have been suspected and the delay of more than 6 years, with dissemination of the tumor, avoided.

\section{Acknowledgements}

We would like to acknowledge the co-operation of the staff of the Chambersburg Hospital, Chambersburg PA, William E Haren MD, surgeon, Michael J Rupp MD, pathologist, and A Thomas Andrews MD, hematologist/ oncologist. The generous assistance provided by $\mathrm{Mr}$ Donald Hay, Administrator, Department of Pathology, Georgetown University Medical Center, is greatly appreciated. W Y C was supported in part by $\mathrm{NIH}$ grant HD31553.

\section{References}

1 Schedewie HK, Reiter EO, Beitins IZ, Seyed S, Wooten VD, Jimenez JF et al. Testicular Leydig cell hyperplasia as a cause of familial sexual precocity. Journal of Clinical Endocrinology and Metabolism $198152271-278$.

2 Cutler GB Jr. Overview of premature sexual development. In Sexual Precocity: Etiology, Diagnosis, and Management, pp 1-10. Eds GD Grave \& GB Cutler Jr. New York: Raven Press, 1993.

3 Grumbach MM \& Styne DM. Puberty: ontogeny, neuroendocrinology, physiology, and disorders. In Williams Textbook of Endocrinology, edn 8, pp 1139-1208. Eds JD Wilson \& DW Foster. New York: WB Saunders, 1992.

4 Rosenthal SM, Grumbach MM \& Kaplan SL. Gonadotropinindependent familial sexual precocity with premature Leydig and germinal cell maturation (familial testotoxicosis): effects of a potent luteinizing hormone-releasing factor agonist and medroxyprogesterone-acetate therapy in four cases. Journal of Clinical Endocrinology and Metabolism 198357 571-579.

5 Chan WY \& Cutler GB Jr. Molecular aspects of precocious puberty. Advances in Molecular and Cellular Endocrinolology 19982 121-141.

6 Laue L. Ligand-independent hormone secretion. Current Opinion in Pediatrics 19957 434-439.

7 Weinstein LS \& Shenker A. G protein mutations in human disease. Clinical Biochemistry 199326 333-338.

8 Lipsett MB, Wilson H, Kirschner MA, Korenman SG, Fishman LM, Sarfaty GA et al. Studies on Leydig cell physiology and pathology: secretion and metabolism of testosterone. Recent Progress in Hormone Research 196622 248-251.

9 Martin MM \& Martin ALA. The syndrome of congenital hereditary adrenal hypoplasia and hypogonadotropic hypogonadism. International Journal of Adolescent Medicine and Health $19851119-137$.

10 Laue L, Chan WY, Hsueh AJW, Kudo M, Hsu SY, Wu SM et al. Genetic heterogeneity of constitutively activating mutations of the luteinizing hormone receptor in familial male-limited precocious puberty. Proceedings of the National Academy of Sciences of the USA $1995921906-1910$.

11 Bar A, Linder B, Sobel EH, Saenger P \& Di Martino-Nardi J. Bayley-Pinneau method of height prediction in girls with central precocious puberty: correlation with adult height. Journal of Pediatrics $1995126955-958$.

12 Saez J. Leydig cells: endocrine, paracrine, and autocrine regulation. Endocrine Reviews 199415 574-626.

13 Landis CA, Masters SB, Spada A, Pace AM, Bourne HR \& Vallar L. GTPase inhibiting mutations activate the alpha chain of Gs and stimulate adenylyl cyclase in human pituitary tumours. Nature $1995340692-696$.

14 Allen LF, Lefkowitz RJ, Caron MG \& Cotecchia S. G-proteincoupled receptor genes as protooncogenes: constitutively activating mutations of the $\alpha 1 \mathrm{~B}$-adrenergic receptor enhances mitogenesis and tumorigenicity. Proceedings of the National Academy of Sciences of the USA 199188 11354-11358. 
15 Van Sande J, Parma J, Tonacchera M, Swillens S, Dumont J \& Vassart G. Genetic basis of endocrine disease. Somatic and germline mutations of the TSH receptor gene in thyroid diseases. Journal of Clinical Endocrinology and Metabolism 199580 2577-2585.

16 Rajpert-De Meyts E \& Skakkabaek NE. The possible role of sex hormones in the development of testicular cancer. European Urology 199323 54-59.

17 Rajpert-De Meyts E, J $\phi$ rgensen N, Müller J, Giwercman A \& Skakkabaek NE. Origin of germ cell tumors. In Sex Differentiation: Clinical and Biological Aspects. Frontiers in Endocrinology 20 , Serono Symposia, pp 45-54. Ed IA Hughes. Norwell: Serono Symposium, USA, 1996.

18 Akre O, Ekbom A, Hsieh CC, Trichopoulos D \& Adami HO. Testicular nonseminoma and seminoma in relation to perinatal characteristics. Journal of the National Cancer Institiute 199688 883-889.
19 Venturelli E, Coradini D, Gornati D \& Secreto G. Growth stimulatory effect and metabolism of testosterone in MCF-7 human breast cancer cells. International Journal of Oncology 1996 8 687-692.

20 Morishima A, Grumbach MM, Simpson ER, Fisher C \& Qin K. Aromatase deficiency in male and female siblings caused by a novel mutation and the physiological role of estrogens. Journal of Clinical Endocrinology and Metabolism 199580 3689-3698.

21 Smith EP, Boyd J, Frank GR, Takahashi H, Cohen RM, Specker B et al. Estrogen resistance caused by a mutation in the estrogenreceptor gene in a man. New England Journal of Medicine 1994331 1056-1061

Received 3 November 1997

Accepted 30 March 1998 